The 16th Economic International Conference

New Challenges and Opportunities for the Economy 4.0, May 7-8th, 2020, Suceava, Romania

\title{
Education Efficiency, Factor of Sustainable Development. An Analysis in Macro 4 Development Region of Romania
}

\author{
Marian ZAHARIA, Rodica-Manuela GOGONEA, \\ Aniela BALACESCU
}

https://doi.org/10.18662/lumproc/ncoe4.0.2020/01

How to cite: Zaharia, M., Gogonea, R.-M., \& Balacescu, A. (2020). Education Efficiency, Factor of Sustainable Development. An Analysis in Macro 4 Development Region of Romania. In C. Nastase (vol. ed.), Lumen Proceedings: Vol. 13. 16th Economic International Conference NCOE 4.02020 (pp. 1-9). Iasi, Romania: LUMEN Publishing House. https://doi.org/10.18662/lumproc/ncoe4.0.2020/01 


\author{
The 16th Economic International Conference \\ New Challenges and Opportunities for the Economy 4.0, \\ May 7-8 ${ }^{\text {th }}, 2020$
}

\title{
Education Efficiency, Factor of Sustainable Development. An Analysis in Macro 4 Development Region of Romania.
}

\author{
Marian ZAHARIA1, Rodica-Manuela GOGONEA2*, \\ Aniela BALACESCU ${ }^{3}$
}

Abstract

The transition to the knowledge-based economy allows the issue of sustainable development to be approached through the evolution of the education system. The process of digital transformation aims to improve the education and skills that manifest differently a regional level due to economic and social factors differently integrated from one county to another. In this context, the paper presents the way in which the performances obtained after taking the baccalaureate exam were influenced on the one hand by the development process of IT infrastructure of high school education, and on the other band by the share of teachers per 100 students. The analysis was performed based on data from development regions and the counties included in Macro-region 4 in Romania, through correlation and regression methods, thus highlighting the efficiency of the relationships between the parameters of education systems.

Keywords: education; high school efficiency; sustainable development; development regions.

\footnotetext{
1 "Petroleum - Gas" University of Ploiesti, 100680, Romania, marianzaharia53@gmail.com

2 Bucharest University of Economic Studies, 71131, Romania, manuela.gogonea@gmail.com

3 "Constantin Brâncuşi” University of Targu Jiu, 210240, Romania, anielabalacescu@gmail.com

* Corresponding author: Rodica-Manuela GOGONEA, manuela.gogonea@gmail.com 


\section{Introduction}

One of the main purposes and directions of action for ensuring the sustainable development at European level, of the Member States of the European Union, as well as especially at regional and local level, is the development of the education system. In this regard, EU regional and urban development policy includes among the 11 priorities that of Investing in education, training and lifelong learning [1].

The sustainable development, in the conditions of current and future economic and social systems, involve the transition to the knowledge-based economy with implications for education systems, especially since improving education and skills is a key part of the overall vision for digital transformation in Europe [2].

In the context of sustainable development, the investments in education and the ensuring of the population's health are a priority [3], especially since their level together with the level of economic development contributes to the formation of the image of human development [4], Romania being from this point of view in the middle of the ranking of European states [5].

On the other hand, it should be emphasized that after 2019, the enrolment rates in Romanian high school education decreased [6], as an effect of reducing the birth rate and increasing migration [7]. Migration is already a global problem with negative effects for source countries [8] especially in the social and economic field, especially since the standard of living in Romania is quite low compared to the European Union average [9], and the economic and social discrepancies between the counties and the development regions in Romania continue to exist [10].

Taking into account these aspects, the paper aims to identify how the development of high school IT infrastructure and the share of teachers per 100 students influenced the performance of the baccalaureate exam in development regions and counties included in Macro region 4 in Romania.

\section{Methodology}

In the analysis of the efficiency of high school education, viewed mainly in terms of passing the baccalaureate exam by high school graduates from the development regions West and South-West Oltenia, components of Macro region 4, started mainly from the available data series on the number of high school graduates who passed the baccalaureate exam in each of the counties included in the two development regions [11]. However, 
taking into account that since 2010 the conditions for completing the baccalaureate exam have been fundamentally changed, the available data series on graduates with a baccalaureate degree refer only to the results obtained from that date. Consequently, in the analysis performed, the data series on the number of students enrolled in high school education [12], the teaching staff in high school education [13], the endowment of high school education with personal computers [14] and the number of high school graduates [15] at regional and county level cover the same period.

The analysis was performed on the basis of five absolute indicators (Students, Teaching staff, Personal computers, High school graduates and Graduates with a baccalaureate degree) and three relative indicators (Number of teaching staff per 100 students, Number of personal computers per 100 students and Share of graduates with baccalaureate degree in the total of high school graduates), used to evaluate the performances at the level of counties, of the two development regions as well as of Macro region 4 , as a whole (Table1).

Table 1. The significances and units of variables used

\begin{tabular}{lll}
\hline \multirow{2}{*}{ Indicator } & \multicolumn{1}{c}{ Signification } & Units \\
& & \\
\hline GBD & Graduates with a baccalaureate degree. & number \\
TS & Teaching staff & number \\
PC & Personal computers & number \\
STD & Students & number \\
GDT & High school graduates & $\%$ \\
TS/ST & Teaching staff per 100 students \\
PC/ST & Personal computers per 100 students & $\%$ \\
B/G & Share of graduates with baccalaureate degree in & $\%$ \\
& the total of high school graduates & \\
\hline
\end{tabular}

The main objectives of the paper were to determine and analyze the correlations between the outcome variables, representing the share of graduates with baccalaureate degrees in the total of high school graduates at the level of each regional structure (z_B / G) and the corresponding factor variables (z_TS / ST and z_PC / ST), representing teaching staff and personal computers per 100 students, as well as identifying and testing regression models that describe the functional links between these variables.

Based on the results obtained on the intensity of correlations, the values of the parameters of the regression models and the values of the 
coefficients of determination, the qualitative aspects were highlighted that describe the efficiency of the relations between the parameters of the education systems in each region included in the analysis. The bilateral $t$ test (Student) was used to test the statistical significance of the correlation coefficient values, and the ANOVA methodology with the $\mathrm{F}$ test (Fisher) was used to verify the validity of the regression models.

To accept or reject the null hypotheses of the $\mathrm{F}$ and t-bilateral tests, $95 \%$ Confidence level (significance level $\alpha=0.05$ ) was used. In some cases, due to the relatively small lengths of the available data series, $90 \%$ Confidence level was chosen (significance level $\alpha=0.10$ ).

\section{Results and discussions}

During the analyzed period, there were increases in the number of teaching staff per 100 students, as well as significant increases in the number of personal computers per 100 students in all counties of the two development regions included in the analysis. However, the expected effects were different from county to county.

\subsection{Correlations and non-correlations.}

An overview, both at the level of Macro region 4 and at the level of the South-West Oltenia and West development regions, underlines the fact that the increase of the number of teachers per 100 students enrolled in high school, as well as the increase of the endowment with computers at the level of high schools led to increased efficiency and quality of education, as evidenced by the results obtained by graduates of baccalaureate exams.

At the level of Macro 4, for the analyzed period, a very strong correlation is highlighted (Table 2) between the share of graduates with baccalaureate degree in the total of high school graduates and the two indicators regarding teaching staff per 100 students and personal computers per 100 students, which highlights their importance on the quality of performance of the education system.

High intensity correlations between the share of graduates with baccalaureate degrees in the total of high school graduates and the other two indicators are also manifested at the level of the development regions included in Macro 4. 
Marian ZAHARIA et al. | Lumen Proceedings 13 | NCOE4.0 2020

Table 2. Correlation coefficients and Sig. (2-tailed) for Macro 4 and its regions

\begin{tabular}{llccc}
\hline \multicolumn{1}{c}{ County } & \multicolumn{1}{c}{ Correlation } & B/G & PC/ST & TS/ST \\
\hline \multirow{2}{*}{ MACRO 4 } & Pearson Correlation & 1 & $0.947^{* *}$ & $0.958^{* *}$ \\
& Sig. (2-tailed) & & 0.000 & 0.000 \\
\multirow{2}{*}{ South_West Oltenia } & Pearson Correlation & 1 & $0.875^{* *}$ & $0.876^{* *}$ \\
& Sig. (2-tailed) & & 0.004 & 0.004 \\
\multirow{2}{*}{ West } & Pearson Correlation & 1 & $0.847^{* *}$ & $0.907^{* *}$ \\
& Sig. (2-tailed) & & 0.008 & 0.002 \\
\hline
\end{tabular}

**. Correlation is significant at the 0.01 level (2-tailed).

It should be noted, however, that although the correlations are also statistically significant in this case at the 0.01 level ( $99 \%$ Confidence level), the values of the correlation coefficients are lower than those recorded at the level of Macro 4. This leads to the conclusion that, in within the two regions, at county level, there are some differences in terms of the efficiency of the education system.

Table 3. Correlation coefficients for the counties of South-West Oltenia region

\begin{tabular}{|c|c|c|c|c|}
\hline County & Correlation & $\mathrm{B} / \mathrm{G}$ & $\mathrm{PC} / \mathrm{ST}$ & TS/ST \\
\hline \multirow{2}{*}{ Dolj } & Pearson Correlation & 1 & $0.821^{*}$ & $0.712^{*}$ \\
\hline & Sig. (2-tailed) & & 0.012 & 0.050 \\
\hline \multirow{2}{*}{ Gorj } & Pearson Correlation & 1 & 0.269 & 0.197 \\
\hline & Sig. (2-tailed) & & 0.519 & 0.639 \\
\hline \multirow{2}{*}{ Mehedinți } & Pearson Correlation & 1 & -0.297 & -0.070 \\
\hline & Sig. (2-tailed) & & 0.475 & 0.868 \\
\hline \multirow{2}{*}{ Olt } & Pearson Correlation & 1 & 0.201 & 0.215 \\
\hline & Sig. (2-tailed) & & 0.634 & 0.609 \\
\hline \multirow{2}{*}{ Vâlcea } & Pearson Correlation & 1 & 0.677 & $0.770^{*}$ \\
\hline & Sig. (2-tailed) & & 0.065 & 0.026 \\
\hline
\end{tabular}

*. Correlation is significant at the 0.05 level (2-tailed).

Of the five component counties of the South_West Oltenia development region, only for Dolj and Vâlcea counties the dependencies between share of graduates with baccalaureate degree in the total of high 
school graduates and teaching staff and personal computers per 100 students are statistically significant (Table 3). Of these, 95\% Confidence level is registered in the case of Dolj county as well as in the case of the correlation between the share of graduates with baccalaureate degree and teaching staff per 100 students in Vâlcea county, and 90\% Confidence level for the correlation between the share of graduates with baccalaureate degree and personal computers per 100 students in Vâlcea County.

On the other hand, there is a reduction in the intensity of correlations compared to existing correlations at the level of the development region. Thus, we can speak of a strong correlation only in the case of the relationship between the share of graduates with baccalaureate degree and personal computers per 100 students, in Dolj County, while for the other indicators the intensities of the correlations are less strong or even medium intensity (the relationship between the share of graduates with baccalaureate degree and personal computers per 100 students in Vâlcea County).

In the case of the other counties, the results obtained highlight the lack of significant links between the share of graduates with baccalaureate degree and the other two indicators. A special case is registered in Mehedinți County, where, although the number of teaching staff and personal computers per 100 students enrolled in high school, in the period 20112014 , increases, the share of graduates with baccalaureate degree decreases. It should be noted, however, that starting with 2015, the share of graduates with baccalaureate degrees enters a normal upward trajectory.

These non-correlations highlight the fact that although the increase in the number of teaching staff and personal computers per 100 students are ways to increase the efficiency of education, in these counties, during the analyzed period, there were other aspects, with dominant negative impact, on the efficiency of the education system.

Unlike the South-West Oltenia development region, in the case of the West development region, of its six component counties (Table 4), only one county identified a non-correlation between the share of graduates with baccalaureate degree and personal computers per 100 students, respectively in Arad County.

In the case of the West region, the highest values of the correlation coefficients between the analyzed indicators were registered in Hunedoara County. They highlight strong links between the share of graduates with baccalaureate degree and personal computers per 100 students and very strong between the share of graduates with baccalaureate degree and teaching staff per 100 students. It should be noted that they correspond to a confidence factor of $99 \%$. 
Table 4. Correlation coefficients for the counties of West development region

\begin{tabular}{llccc}
\hline \multicolumn{1}{c}{ County } & \multicolumn{1}{c}{ Correlation } & B/G & PC/ST & TS/ST \\
\hline \multirow{2}{*}{ Arad } & Pearson Correlation & 1 & 0.594 & 0.674 \\
& Sig. (2-tailed) & & 0.120 & 0.067 \\
Caraş-Severin & Pearson Correlation & 1 & $0.881^{* *}$ & 0.559 \\
& Sig. (2-tailed) & & 0.004 & 0.060 \\
\multirow{2}{*}{ Hunedoara } & Pearson Correlation & \multirow{2}{*}{1} & $0.862^{* *}$ & $0.969^{* *}$ \\
& Sig. (2-tailed) & & 0.006 & 0.000 \\
\multirow{2}{*}{ Timiş } & Pearson Correlation & \multirow{2}{*}{1} & $0.774^{*}$ & $0.869^{* *}$ \\
& Sig. (2-tailed) & & 0.024 & 0.005 \\
\hline
\end{tabular}

*. Correlation is significant at the 0.05 level (2-tailed).

**. Correlation is significant at the 0.01 level (2-tailed).

In the case of the other counties, except for the link between the share of graduates with baccalaureate degree and teaching staff per 100 students from Arad and Caraş Severin, where its intensity is of average value, the links between the analyzed indicators are of significant intensity highlighting a good orientation towards efficiency in the education systems of these counties.

\subsection{Quantitative and qualitative aspects}

Taking into account the results obtained regarding the existence and intensity of correlations between the three variables analyzed, for development regions and counties where statistically significant values of correlation coefficients were recorded, the quantitative relationships between share of graduates with baccalaureate degree and staff were determined. computers and teaching staff per 100 students highlighting the qualitative aspects of the connections between them.

Table 5. Regression models and qualitative indicators at South-West Oltenia region level

\begin{tabular}{|c|c|c|c|c|c|c|c|c|}
\hline Model & $\mathbf{R}$ & $\mathbf{R}^{\mathbf{2}}$ & Sig.F & Regressor & $\mathbf{t}$ & Sig.t & Lower & Upper \\
\hline SWBG(CP/ST) & 0.857 & 0.766 & 0.004 & 1.115 & 4.28 & 0.004 & 0.49 & 1.73 \\
\hline SWBG(TS/ST) & 0.876 & 0.767 & 0.004 & 3.367 & 4.45 & 0.004 & 1.51 & 5.22 \\
\hline
\end{tabular}

Source: elaborated by authors using SPSS

At the level of the South-West Oltenia development region both models (Table 5) are statistically significant (Sig.F $=0.004<\alpha=0.05$ ). Also, all their parameters are statistically significant for $95 \%$ confidence level. 
The analysis of the values of the regressors (coefficients b) highlights the fact that the most important role in increasing the performance of students enrolled in high school in this region is teaching staff per 100 students, increasing by one percentage point can lead to increased student performance by 1.51 to 5.22 percentage points, the most probable increase being 3,367 percentage points.

Another important conclusion is that the increase of the two factors can increase the performance of students only in proportion of $76.7 \%$ in the case of TS / ST, respectively $76.6 \%$ in the case of PC / ST, which means that $24 \%$ of the increase in student performance is due to other factors.

Of the 5 counties included in the South-West Oltenia development region, only in the case of two counties (Dolj and Vâlcea) significant correlations were identified between the analyzed variables. The characteristics of the regression models corresponding to them (Table 6) highlight their validity (statistical significance) (Sig.F $<\alpha=0.05)$.

Table 6. Regression models and qualitative indicators of South-West Oltenia counties

\begin{tabular}{|l|c|c|c|c|c|c|c|c|}
\hline \multicolumn{1}{|c|}{ Model } & $\mathbf{R}$ & $\mathbf{R}^{2}$ & Sig.F & Regressor & t & Sig.t & Lower & Upper \\
\hline DJBG(CP/ST) & 0.821 & 0.674 & 0.012 & 1.925 & 3.53 & 0.012 & 0.591 & 3.27 \\
\hline DJBG(TS/ST) & 0.702 & 0.439 & 0.050 & 5.082 & 2.45 & 0.050 & 0.01 & 10.16 \\
\hline VLBG(CP/ST) & 0.677 & 0.459 & 0.026 & 1.599 & 2.26 & 0.065 & $0.21^{*}$ & $2.98^{*}$ \\
\hline VLBG(TS/ST) & 0.770 & 0.592 & 0.026 & 5.759 & 2.95 & 0.026 & 0.98 & 10.53 \\
\hline
\end{tabular}

$*$. Values corresponding to the $90 \%$ confidence factor $(\alpha=0.10)$.

Source: elaborated by authors using SPSS

Regarding their parameters, the corresponding confidence factors are different. Thus, in the case of parameter $b$, except for the one in the VLBG model (CP / ST) which is statistically valid for $90 \%$ confidence level $(\alpha=$ $0.10)$, the others are statistically significant for $95 \%$ confidence level $(\alpha=$ $0.05)$.

The models, together with the values $\mathrm{R}$ and $\mathrm{R} 2$, highlight several qualitative aspects. Thus, the values of parameters $\mathrm{b}$ corresponding to the contribution of teaching staff per 100 students, to the increase of the efficiency of the education system, both in Dolj county and in Vâlcea county are significantly higher than those corresponding to the contribution of personal computers per 100 students. An increase of one percentage point of TS / ST leads to an increase in efficiency by about 5 percentage points while an increase of one percentage point in CP / ST can lead to an increase in efficiency by about 2 percentage points. The values of the coefficient of determination (R2) highlight the fact that the increases registered in these 
counties regarding Share of graduates with baccalaureate degree were determined only in proportion of about $50 \%$ by the evolutions of personal computers and teaching staff per 100 students, 50\% being the consequence of other factors.

Table 7. Regression models and qualitative indicators at West region level

\begin{tabular}{|c|c|c|c|c|c|c|c|c|}
\hline Model & R & $\mathbf{R}^{\mathbf{2}}$ & Sig.F & Regressor & $\mathbf{t}$ & Sig.t & Lower & Upper \\
\hline WBG(CP/ST) & 0.847 & 0.717 & 0.008 & 1.841 & 3.91 & 0.008 & 0.69 & 2.99 \\
\hline WBG(TS/ST) & 0.907 & 0.822 & 0.002 & 7.434 & 5.26 & 0.002 & 3.98 & 10.89 \\
\hline
\end{tabular}

Source: elaborated by authors using SPSS

Analyzing the models at the level of the West development region, it can be noticed that both models (Table 7) are statistically significant (Sig.F = 0.008 and Sig.F $=0.002$ are smaller than $\alpha=0.05)$. At the same time, the values of the regressors are statistically significant for $95 \%$ confidence level. .

As in the case of the South-West Oltenia development region, and at the level of the West region, in increasing the performance of students enrolled in high school, a significant role is played by teaching staff per 100 students, only that this increase is much higher (on average by 7,434 percentage points). This statement is further justified by the share of $82.2 \%$ those TS / ST returns in increasing student performance, CP / ST contributing only $71.7 \%$.

At the level of the West region (table 8), for all 4 counties, significant correlations were identified, but not between all between the analyzed variables (except for Arad county for the CP variable and Caraş-Severin for TS). Most counties have regression models valid for 95\%, taking into account Sig.F $<\alpha=0.05$ (Table 8), except for Arad County where the validity of the model is for Sig.F $<\alpha=0.1$.

Table 8. Regression models and qualitative indicators of West counties

\begin{tabular}{|l|c|c|c|c|c|c|c|c|}
\hline \multicolumn{1}{|c|}{ Model } & $\mathbf{R}$ & $\mathbf{R}^{\mathbf{2}}$ & Sig.F & Regressor & $\mathbf{t}$ & Sig.t & Lower & Upper \\
\hline ARBG(TS/ST) & 0.674 & 0.454 & 0.067 & 6.745 & 2.23 & 0.067 & $0.88^{*}$ & $12.61^{*}$ \\
\hline CSBG(CP/ST) & 0.872 & 0.760 & 0.005 & 3.962 & 4.36 & 0.005 & 1.74 & 6.18 \\
\hline HDBG(CP/ST) & 0.862 & 0.743 & 0.006 & 2.538 & 4.16 & 0.006 & 1.05 & 4.03 \\
\hline HDBG(TS/ST) & 0.969 & 0.939 & 0.000 & 11.177 & 9.57 & 0.000 & 8.32 & 14.04 \\
\hline TMBG(CP/ST) & 0.774 & 0.599 & 0.024 & 1.391 & 2.99 & 0.024 & 0.25 & 2.53 \\
\hline TMBG(TS/ST) & 0.869 & 0.765 & 0.005 & 6.153 & 4.31 & 0.005 & 2.68 & 9.65 \\
\hline
\end{tabular}

$*$. Values corresponding to the $90 \%$ confidence factor $(\alpha=0.10)$.

Source: elaborated by authors using SPSS 
The regression coefficients, which are statistically significant for $95 \%$ in most counties ( $90 \%$ in Arad county), fact confirmed by Sig.t $<0.05$ (Sig.t $<0.01$ for Arad) have an amplitude of variation of 2,571 percentage points for CP / ST and 5,024 percentage points in the case of TS / ST. Thus, an increase of one percentage point of CP / ST determined the most significant increase of efficiency by 3,962 percentage points in Caras-Severin, while the increase of one percentage of TS / ST allowed an even greater increase of efficiency by 11,177 percentage points for Hunedoara.

In these models, regardless of the factor included in the analysis, teaching staff per 100 students or personal computers per 100 students, values of coefficients of determination (R2) higher than $50 \%$ indicate a significant influence on the share of graduates with baccalaureate degree, at the level of each county, confirming the validity of the models. Share of graduates with baccalaureate degree is significantly influenced by $\mathrm{CP}$, in proportion of $76 \%$ in Caraş-Severin and by TS with approximately $94 \%$ in Hunedoara. The results showed a good orientation towards efficiency in the education systems in Caraş-Severin and Hunedoara counties.

\section{Conclusions}

The only rational perspective of the national evolution for Romania is the consolidation of a new paradigm of sustainable development in which education occupies a priority place.

In this context, the paper analyzed the influence of high school IT infrastructure and the share of teachers per 100 students on the performance of graduates after taking the baccalaureate exam, at the level of development regions and counties included in Macro region 4 in Romania.

The application of correlation and regression methods showed that an increase in the number of teachers per 100 students enrolled in high school, as well as an increase in the endowment of computers in high schools has led to an increase in efficiency and quality of education. The results show a good orientation towards efficiency in the education systems from Dolj, Vâlcea counties from the South-West Oltenia region, respectively in Carass-Severin, Hunedoara, counties of the West region.

It must be emphasized that the radical improvement of the education system and the diversification of the educational offer are of strategic importance, all the more so as they will lead to an efficient labour market and a stronger economy. 


\section{References}

[1] European Commision. An introduction to EU Cohesion Policy 2014-2020; 2014. Available from:

https://ec.europa.eu/regional_policy/sources/docgener/informat/basic/basi c_2014 en.pdf

[2] European Commision. Communication: Shaping Europe's digital future; 2020. Available from: https://ec.europa.eu/info/sites/info/files/communicationshaping-europes-digital-future-feb2020_en_4.pdf

[3] Nastase C, Hodoroaba A. Education - An Economic Growth Factor, The Annals of the "Stefan cel Mare" University of Suceava, Fascicle of The Faculty of Economics and Public Administration. 2010; 10 (2(12)): 53-60.

[4] HDR. Human Development Report; 2018. Available from: http:/ /hdr.undp.org/en/content/humandevelopment-index-hdi. Accessed April 10, 2020.

[5] Zaharia M. Considerations on the Evolutions and Particularities of the Human Development Index in European Countries. Journal of Research and Innovation for Sustainable Society (JRISS). 2019; 1(1).

[6] Ministerul Educației Naționale. Raport privind starea învățământului preuniversitar din România. Guvernul României, Ministerul Educației Naţionale; 2016, p. 22 .

https://www.edu.ro/sites/default/files/_fi\%C8\%99iere/Minister/2017/trans parenta/Stare\%20preuniv\%202016.pdf

[7] Costache L (coord. UNICEF), Fartuşnic C (coord), Jigau M. (coord). Participarea la educație în învățământul secundar superior. UNICEF România, Institutul de Ştiințe ale Educației; 2014, p. 9-10, 22. http://www.unicef.ro/wp-content/uploads/Raport-OOSC-InvatamantSecundar-Superior_final.pdf

[8] Anghel C, Neamtu AC, Neamtu L. Migration and Regional Development In Romania. Annals - Economy Series, 2 Special, Issue; 2017; p. 134-140.

[9] Nitescu A. Issues Concerning the Standard of Living in Romania. Annals Economy Series, 2 Special, Issue; 2016, p. 62-66.

[10] Scutariu AL. The Evolution of Economic Territorial Disparities In Romania. The USV Annals of Economics and Public Administration, 17(2(26)): 21-27.

[11] SCL109G - Numarul elevilor care au promovat examenul de bacalaureat, pe sexe, macroregiuni, regiuni de dezvoltare si judete. Available from: http://statistici.insse.ro:8077/tempo-online/\#/pages/tables/insse-table

[12] SCL103E - Populatia scolara pe niveluri de educatie, medii de rezidenta, macroregiuni, regiuni de dezvoltare si judete. Available from: http://statistici.insse.ro:8077/tempo-online/\#/pages/tables/insse-table

[13] SCL104E - Personalul didactic pe niveluri de educatie, medii de rezidenta, macroregiuni, regiuni de dezvoltare si judete. Available from: http://statistici.insse.ro:8077/tempo-online/\#/pages/tables/insse-table 
Marian ZAHARIA et al. | Lumen Proceedings 13 | NCOE4.0 2020

[14] SCL112C - PC-uri pe niveluri de educatie, macroregiuni, regiuni de dezvoltare si judete. Available from: http://statistici.insse.ro:8077/tempoonline/\#/pages/tables/insse-table

[15] SCL109B - Absolventi pe niveluri de educatie, forme de invatamant, macroregiuni, regiuni de dezvoltare si judete. Available from:

http://statistici.insse.ro:8077/tempo-online/\#/pages/tables/insse-table 